\title{
Forestry Herbicides and the Aquatic Environment ${ }^{1}$
}

\author{
Robert P. Willington ${ }^{2}$
}

\begin{abstract}
The use of herbicides in forestry in British Columbia is regulated by both federal and provincial governments. The Ministry of Environment, Pesticide Control Branch, through the B.C. Pesticide Control Act, controls the handling, selling and application of pesticides once they have been registered by the federal government. A herbicide treatment must have a Pesticide Application Permit, which anyone may appeal through the BC Environmental Appeal Board. Herbicide use in forestry must be based on sound silvicultural judgment. Potential means by which 2,4-D and Roundup may enter the aquatic environment are reviewed. Methods of avoiding this during a forestry herbicide treatment are discussed.
\end{abstract}

\begin{abstract}
Résumé
L'utilisation d'herbicides en Colombie Britannique est régie par les gouvernement fédéral et provincial. Dès qu'un herbicide a été enregistré par le gouvernement fédéral, la Division du Contrôle des Pesticides du Ministère de l'Environnement voit à la manutention, la vente et à l'utilisation des pesticides. Un traitement d'herbicide doit recevoir un permis d'utilisation de pesticides, et toute personne peut en appeller de cette décision auprès du Bureau d'appel en environnement de C.B. L'utilisation d'herbicide en foresterie doit reposer sur une décision bien établie en sylviculture. Le fait que le 2,4-D et le "Roundup" peuvent être retrouvés dans l'environnement aquatique, est étudié. Les méthodes permettant d'éviter cette situation au cours d'un traitement d'herbicide forestier sont abordées.
\end{abstract}

\section{Introduction}

The use of herbicides in forestry in British Columbia is regulated both federally and provincially. Herbicides must be registered for forestry use in Canada in accordance with Trade Memorandum T-1-237, Agriculture Canada (Henigman and Beardsley 1985). In British Columbia, Pesticide Control Branch of the Ministry of Environment (MoE) through the BC Pesticide Control Act, controls the handling, selling and application of registered pesticides (Henigman and Beardsley, 1985). British Columbia also has a Pesticide Application Permit appeal process whereby any individual may appeal the terms of the permit of the BC Environmental Appeal Board. Upon the receipt of an appeal, the Board holds a formal hearing, the results of which are final.

Public and resource agency concerns regarding the effects that the application of herbicides on forest lands may have on associated resources, especially the aquatic environment, have been and will probably continue to be a major factor influencing their use. These concerns must be addressed by those who believe that the use of herbicides is a necessary and safe tool for intensive forestry so that their continued use is assured. This paper discusses some of the means by which two of the herbicides registered for use in forestry, 2,4-D and Roundup, can be used in forestry without causing unreasonable adverse effect to mankind and/or the environment.

\footnotetext{
'Paper given at the Hydrology Working Group Meeting at the Annual Meeting of the CIF in Victoria, B.C. September 1986

${ }^{2}$ British Columbia Forest Products Limited, Resource Planning Group, Crofton, B.C.

${ }^{3}$ amino methylphosphonic acid - major metabolite of glyphosate, indicates degradation is occurring

${ }^{4} \mathrm{~N}$-nitrosoglyphosate - a trace impurity of glyphosate
}

\section{Pesticide Use Permit Application}

All forestry herbicide projects in British Columbia require a Pesticide Use Permit, and all applicators must possess a Pesticide Service Licence (MoE, Pesticide Control Branch). Before applying for a Pesticide Permit, the need to use a herbicide to solve a problem must be determined. The decision to use 2,4-D or Roundup must be based on a sound silvicultural need and justified as being the best method of solving a brush problem. Opponents of herbicide use in forestry frequently challenge the need to use herbicides. Points raised by the public and resource agency personnel regarding the use of herbicides in forestry include:

- if forest management were carried out properly in the first place, there would be no weed problem;

- mechanical control of deciduous weed species is not only safer for the environment, but would help reduce unemployment; and

- some deciduous weed species, such as red alder, improve the nutrient quality of the site and should not be removed.

These concerns should be addressed in the decisionmaking process leading to a brush control prescription. Where 2,4-D or Roundup have been judged to be the most effective treatment, the following will probably be valid:

- Even with the best management, including slashburning to subdue the vigor of residual brush, immediate reforestation with jump stock and follow-up fill planting, the vigor of deciduous weed species frequently exceeds that of the regenerating forest on high site lands.

- Mechanical treatment of deciduous weed species is not necessarily cheaper or safer than herbicide treatment. Resprouting, which may occur after mechanical treatment 
requires more than one treatment. Mechanical brush clearing results in slash which makes use of power equipment dangerous. Mechanical treatment can be an effective tool in special cases such as large alder that can be controlled with one treatment.

- The contribution of nutrients to site quality by red alder may not be sufficient to compensate for the competition for light, nutrients and water to the regenerating forest and the reduction in stocking necessary to accommodate the alder.

\section{Keeping Herbicides Out of the Aquatic Environment}

The best way to avoid exposing the aquatic environment to herbicides is to prevent their entry into it. Contamination may occur by accidental spills, runoff from mixing sites, spray drift or overspray, and runoff or leaching from the treatment area. By recognizing the potential pathways by which herbicides might enter the aquatic environment, one can adopt operational strategies to prevent their entry.

\section{Accidental spill precautions}

Although one cannot guarantee that an accidental herbicide spill will never happen, the probability of occurrence can be reduced to acceptably low levels. The potential for an accidental spill during its transport between the supplier's delivery point and the treatment area should be included in the herbicide treatment program. Strong, leakproof herbicide containers properly stowed and secured in a truck are common sense practices for safe transport. Careful driving is also a sensible precaution. Overturning a truck may cause the strongest of herbicide containers to rupture and release their contents into the aquatic environment.

\section{Mixing site runoff precautions.}

Once the herbicide has been delivered to the treatment area, it is generally mixed with a carrier. This carrier is most frequently water, but diesel oil may also be used. One way to prevent herbicide spilled at the mixing site from entering the aquatic environment is to select a site that is not only a safe distance away from water, but also has a low water table and soils amenable to herbicide adsorption and breakdown. Once the herbicide treatment has been completed, the mixing site should be cleaned up by bashing and burying with lime all used herbicide containers at a safe distance from aquatic environments and connected aquifers.

\section{Spray drift or overspray precautions.}

The first step in preventing the entry of a herbicide into an aquatic environment by spray drift or overspray is to clearly identify the waterbodies associated with the treatment area that can be affected. This may not be as easy as it seems, especially if the waterbodies are small and covered by deciduous vegetation. A small coho rearing channel may be so obscured by brush as to be nearly invisible to even a backpack sprayer operator. Intermittent waterbodies, such as ditches, may be dry at the time of application, thereby permitting relaxation of regulations for herbicide spraying near water. Therefore, not only is identifying waterbodies a necessary preliminary to establishing required pesticide free and buffer zones, but it is best done immediately before the planned treatment to ensure the accuracy of the waterbody classification.

Several regulations must be followed in herbicide application to prevent overspray or spray drift into waterbodies. The most rigorously enforced of these is the pesticide free zone (pfz), generally a 10-meter zone along all waterbodies within which no herbicide is permitted to enter. To ensure this, a buffer zone may be required which, even if it is not treated by herbicide, may 'trap' herbicide originating from the adjacent treatment area, to maintain the pesticide free zone. Generally, a buffer zone is not required for hack and squirt or stump treatment herbicide applications. For backpack spray and aerial herbicide applications, a buffer zone wide enough to ensure the integrity of the pesticide free zone is required. The width of the buffer zone will vary with the:

- method of application (aerial, backpack spray, hack and squirt, stump treatment),

- wind speed and direction at time of application (toward or away from waterbody)

- height and density of vegetation in the buffer zone, and

- terrain

The required buffer strip width can be determined by using Kroma cards. When placed on the ground, these cards show where spray mixed with Rodamine dye has landed. With the cards placed at various distances from the pesticide free zone into the treatment area, the treatment can progress toward the creek with the Kroma cards indicating how close to the pesticide free zone the spraying can go without violating its integrity.

\section{Surface and subsurface herbicide runoff precautions.}

Fortunately, an effectively conducted herbicide treatment usually results in little, if any, chemical directly reaching the soil. When 2,4-D or Roundup is applied to the target species, it is strongly adsorbed onto the plant surfaces and quickly absorbed into the plant tissues. By the time the affected tissues die and fall to the ground, the chemical has usually been detoxified. The amount of sprayed herbicide not intercepted by the vegetation should be very small. Newton et al. (1984) reported that nearly all of the glyphosate aerially applied to a treatment area was intercepted by the vegetation and that rainfall washing of intercepted chemical into the soil ranged from $3.99 \mathrm{mg} / \mathrm{I}$ on day one to $0.002 \mathrm{mg} / \mathrm{I}$ between days 27 and 55 .

Herbicide that falls on a litter covered forest soil is usually readily adsorbed and detoxified microbiologically within a very short time. Newton et al. (1984) reported a half life in forest floor litter of 14 days for glyphosate and Norris (1975) reported that $94 \%$ of the $2,4-\mathrm{D}$ applied to red alder litter was degraded in 35 days.

The breakdown of herbicides on exposed mineral soil is slower than on litter because of less microbiological activity. Newton et al (1984) reported a half life of glyphosate on mineral soil of 40.2 days. Rates for $2,4-D$ may be less that this (NRC 1978), and variable with soil $\mathrm{pH}$, temperature and moisture.

Both Roundup and 2,4-D are adsorbed by most forest soils which prevents them from being readily leached into adjacent aquatic environments. Roundup is adsorbed onto soil organic matter and clay and 2,4-D is absorbed onto soil organic matter and sesquioxides. This combination of soil adsorption and rapid biological detoxification is a major asset in the use of glyphosate and 2,4-D in areas close to water. Roundup or 2,4-D adsorbed to soil particles may, however, move into the aquatic environment through soil erosion. 
Where it is difficult to avoid spraying sites where soil erosion might present this problem, it might be easier to control the erosion rather than try to avoid spraying certain portions of the treatment area.

\section{Overspraying aquatic environments}

Situations sometimes occur where the stream channels within a treatment area are far enough from fish or fish habitat to consider spraying over them. Although this may seem to violate the concepts of pfz's and buffer zones, investigations of the effects of this treatment are somewhat encouraging. Newton et al. (1984) studied the effects of overspraying a stream in which coho salmon fingerlings were released. The aerial application rate of glyphosate (Roundup) was $3.3 \mathrm{~kg} / \mathrm{ha}$ - active ingredient and the streamflow was about $50 \mathrm{l} / \mathrm{min}$. Concentrations of glyphosate in the stream water peaked at $0.27 \mathrm{mg} / \mathrm{I}$ immediately after spraying and dropped to 0 after about seven days and none of the 10 fish collections showed measurable, whole-body levels of glyphosate, $\mathrm{AMPA}^{3}$ or $\mathrm{NNG}^{4}$. In a study of the direct application of 2,4-D to a stream. Norris (1967) found no herbicide residues between 50 hours and 10 months after application. Norris (1975) noted that peak concentrations of herbicides in streams usually occur shortly after application, but they seldom exceed $0.1 \mathrm{ppm}$.

It is to expected that the on-site concentrations of herbicides in oversprayed streams would decrease by the time they reached the downstream fishery habitat through mixing with unsprayed tributaries and absorption to stream substrate sediments. For example, if the concentration of herbicide in the stream in the reach that had been oversprayed were $0.3 \mathrm{mg} / \mathrm{l}$ and the flow in the stream were $10 \%$ of the inflow to the fish habitat reach, the concentration would drop to $0.03 \mathrm{mg} / \mathrm{l}$.

\section{Herbicide Detoxification}

Both 2,4-D and Roundup are readily broken down and detoxified by micro-organisms and are not, therefore, biological accumulators. Roundup breaks down into glycine (a harmless aminoacid), carbon dioxide, water, nitrogen and phosphates, while 2,4-D breaks down into succinic acid. The rate of herbicide breakdown is governed by the degree to which a soil favors microbiological activity. Warm, moist soils that are low in $\mathrm{pH}$ and high in organic matter are generally characterized by sufficiently high microbiological activity that herbicide breakdown will occur rapidly. Most high site quality areas where weeds are likely to be a forestry problem are warm,moist, rich in organic matter and acidic.

Temporary conditions, such as dry soil, may retard the breakdown of 2,4-D or Roundup, but because they are strongly adsorbed to soil particles (2,4-D to anion or positively charged sites and Roundup to cation or negatively charged sites), breakdown will continue when the conditions become more favorable, such as re-wetting of the soil.

Herbicides entering the aquatic environment adsorbed to eroding soil particles, should remain attached to these particles and detoxify at a rate dictated by the microbiological activity in the environment in which they settle out. Herbicides entering the aquatic environment in solution should be adsorbed to stream bank and bed materials and again detoxify at a rate dictated by the microbiological activity in these sites.

\section{Summary}

Roundup or 2,4-D should not enter aquatic environments if they are applied in accordance with label instructions and application requirements stipulated by the agencies granting permit application. The public may appeal a pesticide application permit through the Environmental Appeal Board, a process that generally requires much detail pertaining to the assurance that the proposed herbicide treatment will not cause an unreasonable adverse effect to mankind and/or the environment. An Environmental Appeal Board hearing can result in the cancellation, modification or upholding of a pesticide use permit. Unexpected inspections of ongoing treatments by the Ministry of Environment are designed to ensure that stipulated treatment procedures are being followed. Failure to abide by the conditions of a Pesticide Permit may result in severe penalties.

It is therefore incumbent on the pesticide use permit holder to ensure that the treatment is not only justified silviculturally, but is conducted in strict accordance with the Pesticide Control Act and permit conditions. This requires that all the participants on the treatment be advised of these regulations and conditions and that project supervision be consistent with the need to ensure they are followed.

\section{References}

Henigman, J.F. and J.D. Beardsley, 1985. Forest Pesticide Handbook of British Columbia. Vols. 1-7. Council of Forest Industries and British Columbia Ministry of Forests.

Newton, Michael, K.M. Howard, B.R. Kelpsas, R. Danhaus, C.M. Lottman and S. Dubelman. 1984. Fate of glyphosate in an Oregon Forest ecosystem. J. Agric. Food Chem 32:1144-1151.

Norris, L.A. 1967. Chemical brush control and herbicide residues in the forest environment. p. 103-123. In Proc. Herbicides and Vegetation Management Symposium. Oregon State University.

Norris, L.A. 1975. Behaviour and impact of some herbicides in the forest. In Herbicides in Forestry. Proc. John S. Wright For. Conf. Purdue Univ. Indiana. pp. 159-176.

NRC. 1978. Phenoxy Herbicides - Their Effects on Environmental Quality. National Research Council Canada. No. NRCC 16075. $440 \mathrm{p}$. 